\title{
The meaning and functions of the Swedish discourse marker alltså-Evidence from translation corpora*
}

\author{
Karin Aijmer \\ Göteborg University. Sweden \\ karin.aijmer@eng.gu.se
}

\begin{abstract}
The topic of this paper is to study to what extent a contrastive analysis can contribute to the analysis of discourse markers. Another issue which is explored is whether the contrastive analysis can be enriched by considering the grammaticalization and pragmaticalization of discourse markers. I have chosen to study the Swedish discourse marker alltså and its German cognate also with inferential meaning. It is shown that alltså (and German also) develops either into a question marker or a reformulation marker. By distinguishing two types of reformulation markers we can explain that the consecutive adverb develops meanings such as that is or in other words. It is also shown that there are differences between Swedish and German which can be explained by grammaticalization.
\end{abstract}

Key words: discourse markers, translation, parallel corpus, grammaticalization, pragmaticalization, alltså, also, Swedish, German, English.

\section{Table of Contents}

\section{Introduction 7. Allstå as a question marker}

2. Discourse markers

3. Material and method

4. Grammaticalization and pragmaticalization

5. The data

6. Discourse marker and non-discourse marker uses
8 . The context-adjusting function

9. Reformulation markers

10. German also

11. Zero-correspondences

12. Conclusion

References

* I wish to thank the two referees for their careful examination of an earlier version of the manuscript. 


\section{Introduction}

Discourse markers (and more generally elements which have pragmatic meaning) have quickly become a popular topic in cross-linguistic pragmatics and text analysis because of the challenges they offer to larger issues about language universals and linguistic relativity (cf Aijmer and Simon-Vandenbergen 2003, SimonVandenbergen and Aijmer 2002/2003, Aijmer and Simon-Vandenbergen 2003 and Aijmer and Simon-Vandenbergen, forthcoming).The topic of this paper is to study to what extent a contrastive analysis can contribute to the analysis of discourse markers. ${ }^{1}$ Another issue which is explored is whether the contrastive analysis can be enriched by considering the grammaticalization and pragmaticalization of discourse markers. I have chosen to study the Swedish discourse marker alltså which has a literal meaning which can be paraphrased as so or thus. Alltså has cognates in other Germanic languages such as English, German, Dutch and Norwegian and I have also looked at translations of the German cognate also into English (a direct comparison between alltså and German also is not possible using available translation corpora). Bringing in the German data makes it possible to compare alltså, (German) also and so. ${ }^{2}$

Like other discourse markers alltså has several different meanings which are difficult to reconcile with each other. Vaskó and Fretheim (1997: 235) distinguish two main functions of the Norwegian altså 'both of which have something to do with the regulation of common ground of the participants'. In one of its functions altså (which can be regarded as identical with Swedish alltså) 'serves as a sign that the speaker wants her inferences based on the interlocutors' most recent speech acts either confirmed or disconfirmed' (Vaskó and Fretheim's inference particle (question marker) function 1997: 235; cf Lehti -Eklund 2003 alltså signalling 'reference to different contexts and activities'). In the other function altså is a contextadjusting (modal) particle with the function to check every now and then that the interactants understand each other (Vaskó and Fretheim 1997: 235). The contextadjusting function has also been discussed as 'reformulation' and we can distinguish different 'reformulation marker' uses such as summing up or elaboration.

Fernandez (1994: 240-41) distinguished between 'contrastivité interne' and 'contrastivité externe'. The analysis referred to as 'contrastivité interne' establishes parallels within a single language. An example would be the comparison of alltså as a consecutive adverb with the discourse marker use. 'La contrastivité externe' is concerned with observations of language typological interest and testing hypotheses about what is universal or language-specific. The focus in this study will be on 'contrastivite externe' and in particular on the issues raised by translations and what we can learn from them. The developments of alltså can be further confirmed

1. Earlier studies of alltså do not take a cross-linguistic perspective (cf. Eriksson 1988, Nilsson 2005). The grammaticalization of alltså has been dealt with by Lehti-Eklund (1990, 1997, 2003). The Norwegian discourse marker altså, which is similar to the Swedish marker, has been discussed by Vaskó and Fretheim (1997) and by Fretheim (2000).

2. On the other hand, there is no direct functional correspondence between Swedish alltså and also in English where it has developed into an additive marker. 
by looking at parallel processes in more languages. For instance, Fleischman and Yaguello (2004) found almost complete functional symmetry between French genre que and like in English suggesting that they have been grammaticalized along the same paths. Both the English and the French marker have for instance developed pragmatic functions as focus markers, hedges and quotatives.

When we analyse discourse markers, we make judgements about meanings, for example that two markers have the same meaning or that only one of them is acceptable in a given context. Translations show what meanings the discourse markers have; moreover, if there are different translations of the same lexical item we may assume that these meanings are related (cf. also Nølke 1999 who uses translations between Danish and French to study the polysemy of the French particle donc). Translations and translation corpora make it possible to be more objective about which meanings are the same or different since they give us access to a large number of interpretations besides the linguist's own introspective judgement of what a discourse marker means. Translators are regarded as native speaker informants professionally involved in reflecting on the meaning of the source item and therefore do not share the linguist's dilemma of being simultaneously the observer and 'the observed one' (Dyvik 1998, Noël 2003).

\section{Discourse markers}

Choosing Fraser (1996) as a frame of reference alltså would fit into the category of discourse markers. A discourse marker is defined as 'an expression which signals the relationship of the basic message [the message containing the propositional content, KA] to the foregoing discourse'.

According to Fraser, discourse markers belong to a class of pragmatic markers incorporating elements which are outside the propositional content, i.e. they are non-truth conditional. They do not express a structural relationship between elements of discourse (cf Halliday and Hasan's 1976 theory of cohesion and coherence) but they express relations between discourse elements which can be understood in terms of cognitive principles. Discourse markers have an important role in the interpretation of utterances and encode information about the inferential processes needed to interpret the relations between the utterances, for example in terms of the principle of relevance (Blakemore 2002:79). In this framework (well known in the approach to meaning based on relevance theory) discourse markers contribute to procedural meaning rather than conceptual or representative sentence meaning (their meaning as representing concepts): they "provide instructions to the addressee on how the utterance to which the discourse marker is attached is to be interpreted' (Fraser 1996: 186) 'and are the linguistically encoded clues which signal the speaker's potential communicative intentions' (Fraser, ibid). Their procedural meaning explains their elusiveness since we cannot have direct access to the information they encode (Blakemore 2002: 83).

Fraser refers to markers such as thus or so (correspondences of alltså) as inferential markers 'expressions which signal that the force of the utterance is a consequence which follows from the preceding utterance' (Fraser 1996: 188). Other 
examples of this category are accordingly, after all, consequently, hence, it can be concluded that.

So in the inferential meaning is illustrated in:

(1) A: Marsha is away for the weekend.

B: So, she won't be available until Saturday. (Fraser 1996: 188)

Speaker B states the inference that Marsha won't be available until Saturday as an 'obvious conclusion' from the fact that Marsha is away from the weekend.

Alltså can be an inferential marker but this is not the only function. It can for instance also be an 'elaborative' discourse marker signalling 'that the utterance following constitutes a refinement of some sort on the preceding discourse' (Fraser 1996: 187). It also has other discourse marker uses which will be discussed below.

The term discourse marker will be used in a wide sense here. It includes the use of alltså when it is used with different discourse-structuring functions. No difference is made between discourse marker and modal particle. Alltså in Swedish is, for instance, formally a modal particle rather than a discourse marker when it is found in the middle field since it is syntactically integrated in the sentence.

\section{Material and method}

Recently a number of translation corpora have been compiled specifically tailored for the purposes of cross-linguistic studies. The English-Swedish Parallel Corpus has provided the main source of data for the study of alltså. The corpus (Aijmer et al 1996, Altenberg and Aijmer 2000) consists of almost three million words divided between fiction and non-fiction (40 texts of each category). It can be used crossways: besides going in the direction from originals to translations we can go in the opposite direction and compare translations with their source texts. The EnglishGerman contrastive data have been collected from the Oslo Multilingual Corpus (Johansson 1997). (See also http://www.hf.uio.no/german/sprik/english/corpus.shtml.)

The idea that we can read off meanings and functions from the way a lexical item is translated comes from Dyvik (Dyvik 1998, 2004). Translations are envisaged as mirrors of the meaning of a word or expression in another language. The set of lexical correspondences of the source items in the target language are viewed as a 'translation paradigm'. The paradigms resulting from translation are never 'clean' since some of the translations may be bad and the meanings shown in the translations may reflect the translation process as such. However, they provide 'raw' data and are the input to further analysis of multifunctionality and polysemy.

So (a marker of result or inference) is the closest equivalent of alltså and can perhaps be regarded as a 'literal translation' (Cuenca forthcoming). However, it was used in less than half the cases. The contrastive analysis highlights the fact that the translator draws on many different linguistic resources to render the meanings and functions of alltså. Both frequent and infrequent translations are of interest. Single or infrequent translations are interesting because they may point to new or emergent developments of alltså while the most frequent translations represent meanings or functions which have been conventionalized. 
The translator may also use the strategy of omitting the discourse marker (cf. section 11). So-called zero-correspondences raise questions about 'the elusive character' of discourse markers, i.e. why they are not always needed as explicit signals of coherence relations.

The material I have analysed consists of 230 examples (translations from Swedish into English) and 190 examples in the German contrastive data (German into English). The translations include single translations and zero-correspondences.

\section{Grammaticalization and pragmaticalization}

Grammaticalization is a theory of language change and variation focusing on the origin of change in the communication situation. According to Lehmann (1985: 315 ), languages change 'because speakers do not want to express themselves the same way they did yesterday' and therefore look for new ways of expressing their communicative needs by using the resources available to them. As a result grammaticalization is not a completed process but it can be studied in the new ways we use language.

Grammaticalization creates grammatical morphemes from lexical items by means of syntactic, semantic, pragmatic and morphological processes. In early work (e.g. Lehmann 1985) a scale of grammaticalization was set up to account for the loss of autonomy of the linguistic sign. When a sign loses its autonomy it can be more or less grammaticalized depending on features such as paradigmatization (the tendency for forms to become parts of paradigms), coalescence (increase in morphological bonding and loss of scope), attrition and fixation to a particular slot in the syntactic structure.

Categories which are 'morphologized' (e.g. aspect, number, tense) might safely be said to be part of grammar (Hopper 1991: 19). However, discourse markers are less clearly grammatical and some of the criteria proposed would seem to exclude them. Discourse markers are derived from lexical sources but are for example only weakly integrated in the sentence and they can have wide scope over the whole sentence. This situation has resulted in a lively discussion of the limits of grammaticalization and of the definition of grammar (Giacalone Ramat and Hopper 1998, Traugott 1997 [1995]). According to Traugott, we need to 'go beyond morphosyntax to the relation between syntax and discourse pragmatics, between cognition and communication (Traugott 1997 [1995]: 21). Since discourse markers undergo a number of changes which are not characteristic of grammaticalization they may serve as a testing-ground for what features are necessary for defining grammaticalization (cf. also Brinton 1996, 1998, 2001).

Semantically, grammaticalization has been associated with weakening (delexicalization) and with metaphoric or metonymic shift. Building on Traugott's work, the theory of grammaticalization has been enriched with an account of how new meanings arise as a result of the inferences invited by lexical items or constructions in discourse. Semantic and pragmatic changes are unidirectional and result in subjectification or an increase of subjectification (and intersubjectification). Subjectification according to Traugott is 'the semasiological process whereby 
SPs/Ws [speakers/writers] come over time to develop meanings for Ls [lexemes] that encode or externalize their perspectives and attitudes as constrained by the communicative world of the speech event, rather than by the so-called "real-world" characteristics of the event or situation referred to' (Traugott and Dasher 2002:30).

The relationship between grammaticalization and discourse markers can be regarded as an open question since discourse markers are not fully grammaticalized in the sense of acquiring grammatical meanings or entering into grammatical paradigms (Brinton 1998: 15). There is an alternative to the broad theory of grammaticalization argued for by Traugott (Traugott 1997 [1995], Tabor and Traugott 1998). Following a suggestion by Hansen (1998) we can make room for a category of discourse items which are neither lexical nor grammatical but are semantically closer to the category of function words than to content words. Just as we distinguish between different parts of grammar (syntax, morphology, pragmatics), we can distinguish between grammaticalization and pragmaticalization.

The term 'pragmaticalization' (Erman and Kotsinas 1993, Aijmer 1997) will be used to describe the process responsible for creating (function) words with particular discourse characteristics or pragmatic functions. As a result of grammaticalization alltså develops from a manner adverb to a conjunct adverb. 'Pragmaticalization' accounts for the fact that the grammaticalized form of alltsa (the conjunct adverb) develops pragmatic meanings as a discourse marker such as request for confirmation, repair and emphasis which are characteristic of later stages of semantic and pragmatic change from a source meaning.

The process of pragmaticalization is accompanied by syntactic and prosodic change. As will be exemplified by alltså, markers can occupy several positions in the utterance depending on function and prosody (although it has not been possible to study prosody here).

This study is not diachronic. However, we are lucky to have a study of the different developments of alltså in a historical perspective (Lehti-Eklund 1990). Alltså is a borrowing from German also (all+so) which was originally an emphatic variant of so (Fretheim 2000: 56; Lehti-Eklund 1990). The sentence-internal (manner) adverb ('in this way', 'in the same way') gradually increased its positional range and became a sentence adverb with consecutive meaning through grammaticalization. According to Lehti-Eklund (1990), the transition of the manner adverb (in Swedish) to consecutive meaning takes place in the 16th century and the manner interpretation can be taken to have disappeared around 1680. German also undergoes the same development from manner adverb to a discourse marker. Auer (1996: 317) describes also as 'a spectacular example' illustrating the cline from adverbial phrases in the inner sentence frame via a pre-front field constituent to a discourse marker predominantly used for structuring discourse 'in fixed and circumscribed sequential and/or syntactic environments' (Auer, ibid.).

Further developments (the specifying or paraphrastic function 'that is') and other typically pragmatic functions are found in the 19th century. The process is still going on and 'more pragmaticalized' functions are developing (see in particular Lehti-Eklund 2003). 


\section{The data}

The aim of contrastive analysis is to establish correspondences between elements in different languages. The correspondences can be shown in a translation paradigm mirroring the meanings and functions of the source element in another language. Table 1 shows the translations of alltså in the English-Swedish Parallel Corpus.

Table 1. Translations of alltså in fiction and non-fiction in the ESPC.

\begin{tabular}{|c|c|c|c|}
\hline & Fiction & Non-Fiction & Total \\
\hline so & 36 & 14 & 50 \\
\hline thus & 10 & 21 & 31 \\
\hline that is (i.e.), that is to say, which is to say & 9 & 3 & 12 \\
\hline that meant (that), it meant that, which means & 5 & 1 & 6 \\
\hline then & 5 & 1 & 6 \\
\hline or & 3 & & 3 \\
\hline therefore & 2 & 11 & 13 \\
\hline I mean & 2 & & 2 \\
\hline anyway & 2 & & 2 \\
\hline $\mathrm{OK}$ & 2 & & 2 \\
\hline what he did know was & 1 & & 1 \\
\hline finally & 1 & & 1 \\
\hline must & 1 & & 1 \\
\hline tag question & 1 & & 1 \\
\hline I'm talking about & 1 & & 1 \\
\hline consequently & 1 & 4 & 5 \\
\hline of course & 1 & & 1 \\
\hline question & 1 & & 1 \\
\hline as things stand & 1 & & 1 \\
\hline hence & 1 & & 1 \\
\hline mind & 1 & & 1 \\
\hline so there & 1 & & 1 \\
\hline really & 1 & & 1 \\
\hline in fact & & 1 & 1 \\
\hline in other words & & 7 & 7 \\
\hline however & & 1 & 1 \\
\hline also & & 2 & 2 \\
\hline already & & 1 & 1 \\
\hline thereby & & 1 & 1 \\
\hline accordingly & & 1 & 1 \\
\hline so that & & 1 & 1 \\
\hline you see & 1 & & 1 \\
\hline you know & 1 & & 1 \\
\hline$\varnothing$ & 36 & 24 & 60 \\
\hline other & 5 & 4 & 9 \\
\hline Total & 132 & 98 & 230 \\
\hline
\end{tabular}


The translation paradigm shows the English translations of alltså including single translations and zero correspondences. So, which was the most frequent correspondence, only occurred in $21.8 \%$ of the examples which suggests that although it shares the meaning inference with alltså it is also used in different contexts where it cannot be exchanged for so. Omission was frequent and will be further discussed in Section 11.

Alltså has been translated by another discourse marker in most examples. However, alltså could also be rendered by the modal verb must with an inferential meaning. Besides markers, we find phrases such as 'that meant that' and 'I'm talking about' which do not require inferencing and therefore provide a more specific interpretation than a marker such as so.

The translations of alltså have been divided into fiction and non-fiction. Fiction examples can be assumed to be most similar to authentic speech. When there is a difference between fiction and non-fiction texts this may indicate that a particular function is restricted to spoken language. For example, I mean, $O K$, tag questions, you see, mind, you know occurred only in the fiction data. On the other hand, thus, therefore, consequently, in other words are more frequent in non-fiction.

Alltså is a flexible marker which can be placed in many different positions depending on function. Table 2 shows the translations of alltså according to its position (only the fiction material).

Syntactic position plays an important role for discourse function and will be further discussed below. The following observations can be made here:

— allså in pre-front and front position: so (thus) was the most frequent translation.

- alltså in medial position: the correspondences were so, thus, then.

However, even if so was very frequent omission, was the most frequent translation choice:

— alltså before or after an elliptical structure): the correspondences were for example I mean, that is, or (but never so),

- alltså in final position: some translations which only occurred in this position are $O K$, mind.

The contrastive analysis will focus on the most interesting correspondences. To begin with, we need to discuss the difference between the adverb and the discourse marker (section 6). Sections 7-9 will discuss the correspondences of alltså in its major functions as question marker, attention-marker, reformulation marker (non-paraphrastic) and as a paraphrastic (elaborative) reformulation marker. The contrastive German-English analysis is found in section 10. The problems caused by zero-correspondences are dealt with in section 11. In the conclusion, alltså, so and German also are compared. I also return to a discussion of the semantic and pragmatic processes undergone by alltså. 
Table 2. Alltså in different positions in the utterance.

\begin{tabular}{|c|c|c|c|c|c|}
\hline SO->ET & $\begin{array}{l}\text { pre-front } \\
\text { (appositive) }\end{array}$ & front & $\begin{array}{l}\text { alltså before } \\
\text { or after an } \\
\text { elliptical } \\
\text { structure }\end{array}$ & $\begin{array}{l}\text { medial } \\
\text { (after } \\
\text { the finite } \\
\text { verb) }\end{array}$ & $\begin{array}{l}\text { final } \\
\text { (alltså } \\
\text { as a tag) }\end{array}$ \\
\hline so & 2 & 4 & 1 & 28 & 1 \\
\hline thus & 1 & 3 & 2 & 4 & \\
\hline then & & & & 3 & \\
\hline therefore & & 2 & & & \\
\hline I mean & 1 & & 1 & & \\
\hline $\begin{array}{l}\text { that is (i.e.), } \\
\text { that is to say, } \\
\text { which is to say }\end{array}$ & & & 9 & & \\
\hline $\begin{array}{l}\text { that meant that, } \\
\text { it meant that, } \\
\text { which means }\end{array}$ & & & & & \\
\hline $\begin{array}{l}\text { which means } \\
\text { what he did }\end{array}$ & & 4 & 1 & & \\
\hline know was & & 1 & & & \\
\hline must & & & & 1 & \\
\hline tag question & & & & 1 & \\
\hline of course & & & & 1 & \\
\hline anyway & & & & 2 & \\
\hline you see & & & & & 1 \\
\hline finally & & & & 1 & \\
\hline as things stand & & & & 1 & \\
\hline OK & & & & & 2 \\
\hline mind & & & & & 1 \\
\hline you know & & & & & 1 \\
\hline you see & & & & & 1 \\
\hline hence & & 1 & & & \\
\hline really & & & & 1 & \\
\hline consequently & & & 1 & & \\
\hline I'm talking about & & & 1 & & \\
\hline or & & & 3 & & \\
\hline so there & & & 1 & & \\
\hline$\varnothing$ & & & 4 & 31 & 1 \\
\hline \multirow[t]{2}{*}{ other } & & 4 & & 1 & \\
\hline & 4 & 19 & 24 & 75 & 10 \\
\hline
\end{tabular}




\section{Discourse marker and non-discourse marker uses}

Vaskó and Fretheim (1997) distinguish between the adverb which can be paraphrased as 'consequently' and the inference marker. Consider (2).

(2) Polisen i Norrköping utgick från att Säpo slagit rikslarm.

Säpo ansåg inte att rikslarm var en åtgärd som åvilade säkerhetstjänsten.

Alltså hade ingen ens slagit larm.

(JG1)

'The police in Norrköping assumed that Säpo had put out a nationwide alert.

Säpo did not regard a nationwide alert as a measure within its scope.

So no one put out an alert.'

Vaskó and Fretheim's suggestion is that the adverb can be paraphrased as 'consequently' ( $\mathrm{x}$ is an inevitable consequence of y). Säpo did not regard a nation-wide alert as necessary. As a consequence of this no one put out an alarm. However, it is not easy to make a distinction by means of paraphrasing or looking at translations. According to Schiffrin, the function of the causal adverb is 'to express a causal relation or result' (Schiffrin 1987: 202) which is distinct from expressing an inference ('an interpretation which uses background knowledge') (Schiffrin 1987: 205; see also Brinton 1996: 198 for more discussion of the distinction).

In (3) the meaning is inference rather than cause-result:

(3) Eftersom jag fick en känsla av att hon var mörkhyad kanske vi redan från början bör lägga lite extra vikt vid att kontrollera flyktingar och förläggningar. Sedan får vi avvakta vad teknikerna kommer fram till.

- Vi vet i alla fall att det inte är något brott begånget, sa Hansson.

Vår uppgift blir alltså att fastslå vem hon var.

(HM1)

'Since I had a sense she was dark-skinned, we can start by putting a little extra focus on checking on refugees and the refugee camps.

Then we "ll have to wait for what the techs come up with."

"At any rate, we know there was no crime committed," said Hansson.

"So our task is to determine who she was.'

It is apparent from the preceding context (the police don't know who she is) that they will have to find the woman's identity. When alltså is inferential it is as if the speaker has done some calculation to arrive at the conclusion. For example, in (3) so is an inference marker signalling that Speaker A believes that speaker B has already been informed (but needs to be reminded) or that he or she can infer something on the basis of the context or background knowledge. When alltsa has the function to present new information as the result of inference it will be referred to as a marker of conclusion following Fraser (1996: 188), who defines inferential markers as 'a class of expressions which signal that the force of the utterance is a conclusion which follows from the preceding discourse'. 


\section{Alltså as a question marker}

So can have the function of question marker although this meaning is not always easy to distinguish from the inferential meaning. When alltså can be translated by so or by then (but not by thus) this can show that it is a request for confirmation. Vaskó and Fretheim (1997: 253) make the following observation:

With the inference particle the speaker asks the hearer to confirm a belief which is grounded on a pragmatic interpretation of the interlocutor's most recent illocutionary act, or on the most recent communicative event, which may consist of a number of illocutionary acts.

The relationship to the adverb and the meaning result is clear. However, the meaning is inferential. Depending on the context the meaning signalled by alltså can have an assertive or interrogative interpretation. In (4) it is clear from the construction (a second person subject) and probably intonation that the speaker is interested in finding out what the hearer has seen:

(4) Men snuten nöjer sig inte med jodå, den där har man väl sett.

Mer vill han veta.

Du har alltså sett den.

När senast?

Vems är den?

'But the cop's not happy with a yes, course I 've seen that before.

He wants more.

So, you 've seen it before then.

When did you see it last?

Whose is it?'

In (5) the speaker may have had a contrary opinion and therefore asks for confirmation. The request for confirmation meaning is further signalled by the question mark in the translation and by the fact that the hearer takes over the turn in order to produce a confirmation:

(5) "Du är alltså ingen jävla nolltaxerare."

"Nej, men jag skulle inte ha något emot att betala mer skatt, fast det är mer komplicerat än du tror."

(JG1)

"'So you "re not one of those damned zero-taxpayers?"

"No, and I would n't have anything against paying more taxes — it 's more complicated than you think."”

In (6) the translation with then and the question mark suggest that the translator has interpreted alltså as a question marker. The speaker requests confirmation about something which can be inferred from the preceding context: 
(6) "Nio eller tio veckor."

Jag sa ingenting i ett par ögonblick, och han tittade snabbt upp med alerta och frågande ögon.

"Ett stelt förband, alltså?"

" Nine or ten weeks."

I did n't say anything for a moment or two and he looked up fast, his eyes bright and quizzical.

"A cast, then?" he said.'

When alltsa is a request for confirmation the translator can choose to explicitly render the question meaning with a question tag:

(7) "Problem?"

"Bara de gamla vanliga."

"Hemmavid, alltså?

(MW1T)

“"'Trouble?"

"Only the usual."

"Domestic, eh?"

\section{The context-adjusting function}

In other cases alltså cannot be defined as an inferential or question particle (i.e. there is no indication that the speaker believes something and wants the hearer to share this assumption). A common function of alltså is to avoid misunderstanding by clarifying, reformulating or reinterpreting what is said in order to avoid a disruption of common ground. Vaskó and Fretheim (1997: 245) describe this function as context-adjusting:

In order to avoid misunderstandings stemming from the hearer's failure to draw one or more significant inferences on the basis of what is said, the speaker can avail herself of certain context-adjusting comments added at strategic points in the discourse, for example at a point where it seems natural to try to extract the gist of the conversation (summing up), and to check whether the speaker's and the hearer's contextual assumptions converge or diverge.

In the example below alltså has context-adjusting function, i.e. it cannot be understood as a question-marker.

(8) En fråga som innefattade pojken, $\mathrm{K}$ och hans hustru, Ruth, Pasqual Pinon, Maria — och i viss mån mig själv, om nu Heisenberg hade rätt $i$ att den som ser förstör bilden.

Alltså: det här är frågan, om än deformerad.

'One question, which included the boy, $\mathrm{K}$ and his wife, Ruth, Pasqual Pinon, Maria - and possibly myself, if it happens that Heisenberg is right about the observer destroying the observed.

Thus: this is the question, even if deformed.' 
Alltså occupies the pre-front field position. In the pre-front field alltsa is only loosely or appositionally attached to the following sentence (a topological position Auer 1996 refers to as the pre-front field). The pre-front and the front field can be distinguished in Swedish by means of word order. Swedish is a V2 language, i.e. the finite verb occupies the second position in the main clause. It follows from the so-called V2 constraint in the Scandinavian languages that if the adverb is placed first in the utterance this should bring about inversion of the subject and verb. In the example below alltsa has been topicalized, the subject therefore must come after the verb.

\section{Alltså hade ingen ens slagit larm}

Lit: 'So had no one even put out an alert'

When alltså has pre-front position it is used for expressing relations between discourse elements. For example, alltså functions as an attention- marker drawing attention to a following topic, point in the discussion, etc. This function is rendered in the translation by so or thus. In both (8) and (9), so (thus) retains some traces of the meaning of result although the meaning is mainly forwards-pointing:

(9) Han såg vad hon tänkte.

Han tänkte: Alltså.

Om en gammal kund sade "blek sherry" visste båda vad det var fråga om. (SCO1)

'He could see what she was thinking.

He thought: So.

If an old customer said 'pale sherry', they both knew what was meant.'

In example (10) the translator has chosen to render the attention marker function now look rather than so:

(10) Alltså, Hugo, du lovar att hjälpa mig med Mujid?

'Now look, Hugo, you promise you 'll help me out with Mujid?'

$(\mathrm{MD} 1 \mathrm{~T})$

Although Auer (1996: 318) describes this function as the most frequent one in spoken German, it was poorly represented in my data.

The relation expressed between the elements can be that of reformulation rather than inference. Reformulation markers have a context-adjusting rather than inferential or question function.

\section{Reformulation markers}

The notion 'reformulation' used for instance by Rossari (1994) needs to be defined. Reformulation markers do not combine propositions but have the property to indicate something which cannot be expressed by the text structure alone, i.e. without these markers. They have functions such as rewording, correcting, elaborating, 
paraphrasing. Following Rossari (1994) I shall distinguish two main functions of reformulation markers. Non-paraphrastic reformulations typically recapitulate or resume something from the preceding discourse. They are realised by markers such as finally, after all, OK, anyway, in fact, anyhow, well. ${ }^{3}$

In (11) alltså is translated as in fact. Besides summing up what has been said the marker indicates some deviation from what was expected (the space seemed to be large but in fact it wasn't):

(11) Den faktiskt uthyrda lagervolymen var alltså inte alls så stor som man trodde. (BB1)

'The space actually rented out was, in fact, not as large as the client thought.'

Anyway can be a non-paraphrastic reformulation marker when it is used to 'resume a trend of thought' (Ferrara 1997: 350):

(12) Vad Jannes farsa var för något hade jag ingen aning om.

Cykelmekare kanske?

Nu snackade alltså Janne och farsan för fullt med varandra, så att jag nästan kände mig undanpetad.

(PP1)

'I 'd no idea what Johnny's dad was.

Bicycle mechanic maybe?

Anyway, Johnny and Dad were pattering away twenty to the dozen, so I felt a bit out of it.'

I have also analysed $O K$ as non-paraphrastic. $O K$ does not link one proposition to another but recapitulates something with the implication that a correction takes place:

(13) Pannan var inte lätt att uttala sig om. Röda luggen skymde sikten.

Fräknig alltså.

Och rödhårig.

Då var han väl grönögd också?

(PP1)

'It was n't so easy to comment on his forehead.

His red quiff blocked the view.

$O K$, freckly.

And red-haired.'

Also in (14) $O K$ recapitulates or reformulates something which ought to be obvious from the preceding context:

3. Cf. Gülich and Kotschi (1996: 61) for French examples: tout compte fait, somme tout, après tout, en fin de compte, finalement, en définitive, en tout cas, de toute façon/manière, en fait, de fait, en réalité, au fond. 
(14) Sa han och började med långtråkig noggrannhet dra igenom hela katalogen: Apollo (svenska kungen alltså!) och Maraton och Monarped, vet du, svenska moppar, fast dom bellar över åttahundra.

(PP1)

'He claimed, and proceeded to go through the whole catalogue in boring detail: Apollo (the pick of the Swedish makes, OK?) and Marathon and Monarped, right, Swedish mopeds, though they 'll set you back 800 kronor at least.'

There is a small step from 'non-paraphrastic' to 'paraphrastic' (elaborative) markers. The paraphrastic alltså has translations such as that means, which means, that is, that is to say, in other words, I mean, I'm talking about (cf Gülich and Kotschi 1996: 58ff). The translations make clear that alltsa has the metalinguistic function of clarifying, specifying, expanding or elaborating without changing the semantic content.

In (15) that is has the function to make explicit 'which Schweitzer' is meant.

(15) Schweitzer, Albert alltså, säger emellertid runt sekelskiftet att de där körerna passar bättre till det religiösa ändamålet, däremot ariorna...

(GT1)

'Schweitzer - Albert that is - said, around the turn of the century that these choruses work better for the religious purpose; on the other hand, the arias...'

That is specifies or gives further information about the referent mentioned earlier.

The non-paraphrastic reformulation marker has a function which is close to the conclusion meaning associated with the adverb since it has functions such as summing up, concluding. At the same time the marker signals that the speaker dissociates him/herself from what is said (according to Gülich and Kotschi 1996 the markers express different degrees of 'Distanzierung'). The existence of a special nonparaphrastic function related to both conclusion and elaboration can explain that alltså can have what seems like incompatible meanings.

In the paraphrastic category we also find in other words. Like that is it focuses on the code itself, i.e. it is metadiscoursal marker (Schiffrin 1987: 303) which elaborates what has been said before by paraphrasing it:

(16) Konflikter är utmärkta grogrunder för förnyelse.

Problem kan alltså ses som fiender om de uppstår utanför vår kontroll, men kan ses som vänner, om de uppstår genom oss.

Det kan alltså ibland finnas all anledning att vårda sina problem och t $\mathrm{o} \mathrm{m}$ kriser.

'Because conflicts are an excellent breeding grounds for innovation.

Thus, problems can be regarded as enemies if they develop from factors outside our control, but can be regarded as friends, if they emerge though our own self-renewal processes.

In other words, there could be all the reason in the world to nurse our problems and even crises.' 
I mean introduces a clarification of something which has been said before and might have been misunderstood without the marker:

(17) “Klockan 17.00, hurså?'

"Därför att jag tänkte vi skulle fira att jag torskat som fortkörare för första gången och dessutom åkt fast med hjälp av kvinnlig personal.

Alltså jag skulle vilja bjuda er på middag."

“"Five o'clock - why?"

"Because I thought we could celebrate my getting caught speeding for the first time, and being nabbed by female personnel at that - I mean, I 'd like to invite you to dinner."'

I mean helps to establish that the speaker and hearer are on common ground in a situation where the speaker's intention may be misunderstood.

In the following example, that means as a translation of alltså signals that what follows expands or elaborates an idea in the preceding context:

(18) Om ett tag började smårötterna gå av, det hördes att det small djupt nedi jorden då dem brast, och Jakob tänkte: han rör sig ändå, han är icke oövervinnelig.

Ett halvvarv i taget alltså, och då veven är nedåt kan man luta sig mot henne och vila sig något andetag.

'In a little while the small roots began to give way, you could hear a snap far down in the earth when they broke, and Jacob thought: "All the same it is moving, it is not invincible."

That means half a turn at a time; and when the winch is going down one can lean against it and rest for a few breaths.'

Similarly in (19), that means signals that what follows is an expansion or elaboration of a preceding idea ('we haven't been told that there has been an accident'). What has happened is therefore likely to be a crime. If the translator had chosen so instead the meaning would have been conclusion rather than elaboration.

(19) Det är allvarligt.

Hade det hänt en olycka hade vi fått veta nånting vid det här laget.

Men det har vi inte.

Alltså är det fråga om ett brott.

(HM2)

"“They are serious.

If there had been an accident, we "d have heard about it by now.

But we haven't.

That means we 're dealing with a crime.'

The speaker adds something so that the hearer will not draw the wrong conclusion. 


\section{German also}

We cannot compare German and Swedish directly by using translations from German into Swedish. However the translations of German into English suggest that Swedish alltså and German also have developed in a similar way although there are some differences (see Table 3 for the English translation of German also).

Table 3. Translations of German also into English.

\begin{tabular}{|c|c|}
\hline so & 46 \\
\hline therefore & 22 \\
\hline thus & 18 \\
\hline that is (to say) & 15 \\
\hline then & 10 \\
\hline in other words & 9 \\
\hline that (this) means, meant, which meant that & 5 \\
\hline right then, all right (also gut) & 4 \\
\hline also & 2 \\
\hline well & 2 \\
\hline and so & 2 \\
\hline consequently & 2 \\
\hline question & 2 \\
\hline so (but) also & 2 \\
\hline so must & 3 \\
\hline in that case & 1 \\
\hline na also & 1 \\
\hline in the form of & 1 \\
\hline and particularly & 1 \\
\hline so that & 1 \\
\hline must & 1 \\
\hline just as & 1 \\
\hline like & 1 \\
\hline namely & 1 \\
\hline and & 1 \\
\hline yes of course, (doch also) & 1 \\
\hline just & 1 \\
\hline well then (nun also) & 1 \\
\hline nevertheless & 1 \\
\hline and hence & 1 \\
\hline it may be of course & 1 \\
\hline$\varnothing$ & 22 \\
\hline other & 8 \\
\hline Total & 190 \\
\hline
\end{tabular}


For example, we find translational evidence for the meaning inference (so, therefore, thus, consequently, hence as well as the modal must). The paraphrastic or elaborative function is reflected in the large number of translations with that is and in other words. Also as a question particle (asking for confirmation) was translated by so in (20) and (21).

(20) Was macht Leni also?

'So what does Leni do?'

(21) Aber die bestellen ja schließlich nicht die Böden.

Also doch die Bauern?

Aber die wurden in die EG-Klemme gesteckt, müssen düngungsintensive Überproduktionen betreiben, um ihrerseits wirtschaftlich zu überleben... (UB1)

'But they do not till the soil, after all.

So it is the farmers?

But they were squeezed by the EEC, they have to practice fertilizer-intensive overproduction in order to survive...'

Also as a question particle is not translated when it occurs in a subordinate clause:

(22) Fragt sie dann, ob sie also Republikaner sind.

Und sie werden ebenfalls verneinen.

(ERH1)

'Then ask them if they are republicans.

They will answer that in the negative also.'

In (23) the question particle also is translated with then but so would also have been possible.

(23) Und sie werden ebenfalls verneinen.

Was also sind sie?

Sie wollen es nicht wissen.

(ERH1)

'They will answer that in the negative also.

What are they, then?

They do n't know.'

In German alltså was translated with well then, all right (then). Moreover, well in English originals was translated into German also (47 examples). In Swedish alltså was never translated as well (well then, all right then). On the basis of the translation I would describe also as a frame marker with the function of summing up: 
(24) und doch: Karten zu lesen, hatte Leni gelernt: diese so sehr gewundene schwarze Linie zwischen Hunsrück und Eifel, die Mosel, wurde von Leni doch durchaus nicht nur als schwarze gewundene Linie, sondern als Zeichen für einen wirklich vorhandenen Fluß erkannt.

Also. Das Experiment gelang: Leni lernte Noten lesen, mühsam, widerstrebend, oft vor Wut weinend, aber sie lernte es -

( H E B )

'and yet: map reading was something Leni had learned: that black line twisting and turning between the hills of the Hunsrïck and the Eifel, the Moselle River, was recognized by Leni not as a twisting black line but as a symbol for an actually existing river.

All right then.The experiment worked: Leni learned to read music, laboriously, resisting it, often in tears of rage, but she learned it - '

(25) Elle klopfte ein Achtungszeichen auf meine Knie, dann sagte sie: "Also gut: du mußt ihm unbedingt sagen, was du gesehen hast."

'Elle tapped me on the knee for attention and said: "All right: you simply have to tell him what you saw."'

(26) Hätten uns nicht auf Verhandlungen eingelassen über unser angestammtes Recht, den Zugang zum Hellespont.

Nun also.

Das Ergebnis in Kurzfassung: Die Griechen einigten sich nicht über die Bedingungen,

'We would not have entered into negotiations about our hereditary right: access to the Hellespont.

Well then, to sum up the result: The Greeks did not agree on terms,'

In the following examples the English original contains well which has been translated as also:

(27) "What kind of things?"

"Well, a double boiler.

“"Was für Sachen?"

“Also - einen Doppelkocher.'

In the Swedish translation $j a, j o$, nåja with the function to express hesitation or reservation would be used rather than alltså (cf. Aijmer and Simon-Vandenbergen 2003).

Also is used both in questions and in imperatives in German. It was not translated in the example below which suggests perhaps that its function is mainly emphatic in imperatives: 
(28) Ihr kennt dieses Zeichen, das ich trage.

Also holt ihn her!"

'You know this sign I am wearing.

Go and get him."”

On the other hand, also was not found in final position in an emphatic or intensifying function.

\section{Zero-correspondences}

Besides explicit translations, omissions (zero-correspondences) are of interest. Omission is frequent above all when alltså had medial position (omission $41 \%$ of the examples). On the other hand, omission did not occur when alltså was in front position.

Omission of discourse markers seems to be a rather general phenomenon. For example, concessive discourse markers are often omitted in translation. Two concessive connectors which are often left untranslated in Swedish translations from English are $i$ alla fall (anyhow) (31\%) and ändå (yet) (28\%) (Aijmer and Altenberg 2002: 22). In this context it is interesting to compare also Fretheim and Johansson (2002) who found that Norwegian likevel (lit. anyhow) was omitted in 1/5 of the examples in the English translations in the English-Norwegian Parallel Corpus.

To begin with, it may be suggested that we can explain omission in terms of general translation strategies. For example, because alltså (and other discourse markers) are so frequently omitted it may be hypothesized that omission of discourse markers is a universal strategy of translation. However, it has been shown on the basis of large quantities of translated text that a translation tends to be more explicit than the original text (Baker 1995). For example, Behrens (2004) found that the weakly consequential dermed (literally 'therewith') in Norwegian was much more frequent in translation than in texts originally written in Norwegian. Thus although translation strategies may play a role we need to look at other factors.

Another hypothesis is that omission can take place if there are other functional cues in the context making the discourse marker redundant. In (29) and (30) the inferential alltså need not be translated since its function is already indicated by that's where, that's how long with the function of introducing a conclusion:

(29) Husen där uppe till höger är Domme.

Där bor alltså Sigbrit Mård och Folke Bengtsson.

Vill du åka dit?

"“Those buildings up there to the right, that "s Domme.

That 's where Sigbrit Mård and Folke Bengtsson live.

Do you want to drive up?"' 
(30) Det var inte vad jag ville vara.

Det var något jag inte bett om.

Jag slöt ögonen och kände mig illamående.

Så långt hade det alltså gått sedan sist.

'It was n't what I wanted to be.

It was n't anything I had asked for.

I closed my eyes, feeling sick.

That 's how long it had been since the last time.'

Alltså as a question particle need not be translated if it is found in a question:

(31) Men du har alltså inga misstankar om brott?

'But you do n't suspect any foul play?'

(32) Hon förstod alltså vad du sa?

(HM1)

'She understood everything you said?'

In (33), the clarifying function is sufficiently expressed by 'what I mean is':

(33) Jag menar alltså att om Sigbrit är död så finns det många hundra ställen hon kan finnas på.

(SW1)

'What I mean is, if Sigbrit 's dead, there are several hundred places she might be.'

We have so far discussed general factors explaining omission. A question which needs a clearer answer is when and why a discourse marker can be deleted. What is particularly interesting is the extent to which discourse markers are needed to express the relations between parts of the text. If discourse markers have procedural function we might for example expect them to be helpful but dispensable elements. Aijmer and Altenberg (2002: 22) point out that 'most connectors can be omitted if the context is clear enough'. For example, in (34) the relationship between the clauses is understood on the basis of the context and the ordering of the clauses.

(34) Han tyckte om cassataglassen.

Varje gång K gick dit köpte han alltså med sig ett paket.

(PE1)

'He liked the cassata ice cream.

Each time $\mathrm{K}$ went along there he bought a carton to bring.'

Similarly, in (35) no misunderstanding could come about if the discourse marker is omitted. 
(35) Sen dess är hon försvunnen.

Wallander rynkade pannan.

Idag var det måndag.

Hon hade alltså redan varit borta i snart tre dygn.

(HM2)

'That's the last we know."

Wallander frowned.

It was Monday today.

She'd already been away for three days.'

Omission does not mean that there is no appropriate translation equivalent. The translator could equally well have chosen so or thus in the translation but the interpretation is clear without the discourse marker. On the other hand, as Fraser (1996: 195) points out, it is doubtful that all possible relationships between sentences can be recognized without a discourse marker. It has even been suggested (Hansen 2006: 26) that some markers 'can never be deleted without radically altering the range of possible interpretations of the discourse'. The French de toute façon is such an example according to Hansen:

(36) Max a oublié de se rendre à la réunion. De toute façon, le comité a décidé d'ajouter cette réunion.

'Max forgot to go to the meeting. In any case, the committee decided to adjourn the meeting.'

De toute façon is needed to prevent a causal interpretation of the second sentence. We can compare Rossari (1994: 6) who notes that 'a marker of reformulation such as "de toute façon" or "en fait" cannot be suppressed without a change of function'.

We also need to explain why omission is particularly frequent when alltså has medial position. A parallel can be drawn with modal particles in Swedish which are generally omitted in the translation. When translating modal particles from Swedish into English one cannot expect to find any direct correspondence (Aijmer and Altenberg 2002: 30). As a result, modal particles are often not translated at all. For example, the Swedish modal particle ju ('of course') was not translated in $65 \%$ of the examples (Aijmer and Altenberg ibid.). A comparison can be made with alltså in front or pre-front position where the link to the preceding context is stronger which may be why it is translated.

When alltså occurs in final position it has developed further from the lexical source. In the examples below, alltså is used to give emphasis to what is said. It is a sign of its weakened meaning that it can easily be omitted from the translation:

(37) Janne rev ut slangen, fortare än det går att säga det, och hittade rätt på själva hålet utan att tveka, och putsade och slipade och strök ut solution och slabbade dit en laglapp och stoppade in slangen och vrängde däcket på plats igen utan att använda några verktyg.

Med bara fingrarna, alltså. 
'Johnny had the inner tube out before you could say It, and homed in on the hole straightaway, no messing, and polished and smoothed down and squeezed out solution and slapped on a patch and stuffed the tube back in again and wrenched the tyre back into place without using any tools at all.'

Just his bare hands.

(38) -Med vad?

Jag håller på med råttorna!

-Vad vill de, professorn alltså och de andra, vad vill de att jag ska göra??

(PCJ1)

'-With what?

I have to see to the rats!

-What do they want, the professor and all the others, what do they want me to do??'

(39) Det första stycket "Jauchzet, frohlocket, auf preiset die Tage", det heter egentligen: "Tönet Ihr Pauken..." en världslig text och stämmer fan så bra, förlåt, i sitt världsliga sammanhang, en högst vanlig historia framförd $i$ en sal vid hovet, i ett slott, med en grupp studenter dåligt betalda.

Lakejmusik, alltså.

'The first piece, 'Jauchzet, frohlocket! auf, preiset die Tage,' is actually called 'Tönet Ihr Pauken...', a secular text, and it works damn well, if you 'll pardon the expression, in its secular context.

A familiar story, performed in a hall at court, in a palace, by a group of poorly-paid students.

Music for lackeys.'

(40) A, B, C, D. .

Svaret är Y. Efter Y:et kommer en liten pust ...

P!

I nästa ljud visar hon tänderna . . .

S!

Sedan grimaserar hon som om hon stuckit foten i iskallt vatten ... $\mathrm{I}$ !

-Ypsilon, säjer hon alltså.

(PCJ1)

'A, B, C, D.. .

The answer is Y. After the Y comes a little puff of air... $\mathrm{P}$ !

Making the next sound, she bares her teeth...

S!

Then she grimaces, as if she ' $\mathrm{d}$ stuck her foot in ice-cold water...

$\mathrm{I}$ !

— Ypsilon, she 's saying.' 
Omission of a translation equivalent may be a cue to pragmaticalization since it suggests that the meaning of alltså has been weakened.

\section{Conclusion}

Grammaticalization and pragmaticalization have been of great help in understanding the polysemy of alltså and how the different meanings and functions are related. Alltså has two main functions as an inference particle (marking inference or a request for confirmation) and the context-adjusting function (Vaskó and Fretheim 1996). In addition, alltså is a reformulation marker (i.e. it has functions on the structural level such as correction, paraphrasing, clarification, elaboration). Grammaticalization in this article has been understood in a narrow sense as involving changes mainly of a morphosyntactic nature. Pragmaticalization, on the other hand, focuses on processes such as 'pragmatic strengthening' and the role of conversational implicature to convey new meanings. Pragmatic markers can be derived from lexical sources 'either transparently' or by conventionalisation of conversational implicatures (Brinton 1996: 270). The older meanings can coexist with new ones or leave a trace when an old meaning is replaced by a new one. For example, alltså may be used both as an adverb or a discourse marker with inferential or conclusive meaning (but the meaning of manner adverbial has disappeared). Conventionalisation of implicatures accounts for the semantic shifts which take place, for example, from a marker with context-adjusting function to a non-paraphrastic reformulation marker or an elaborative paraphrastic marker. In a diachronic perspective, these meanings can be related without assuming that alltså is homonymous.

Alltså has developed from a manner adverb to an adverb with the meaning of cause or result and further to a discourse marker with inferential meaning (a marker of conclusion) which can also be used as a request for confirmation. However, the adverb can also develop along a different trajectory to a marker of reformulation.

The position of alltså is important for what changes are possible For example, alltså in the pre-front field can develop a 'forwards-looking' function introducing a new aspect of the topic, a new turn or a move (a function described here as a frame). The 'loose' attachment in the pre-front field explains that alltså can receive this function. According to Auer (1996: 318), 'if [German] also moved into the front field [from the pre-front field] it would resume its ordinary consecutive meaning'. The use of alltså in final position seems to be idiosyncratic. Nilsson (2005) found, for instance, that more than half of her examples were placed finally (in a spoken corpus of Swedish where all the speakers were adolescents) and that the most common function of alltså was emphatic.

Alltså has also become a discourse marker with the meaning 'in other words', 'or', 'that is', 'I mean', 'that means'. That means functions on the syntactic level while in other words, I mean, etc are markers either following or preceding an elliptical structure. As a reformulation marker, alltså (or also) is also used with translations such as finally, in fact, anyway, which are closer to the inferential 
marker but signal that the speaker distances him/herself from what is said. The markers have in common the reformulation function ('an utterance $\mathrm{q}$ will be understood as a reconsideration of $\mathrm{p}$ according to the instructions of the discourse marker'; cf. Rossari 2004). By distinguishing between two types of reformulation markers we can explain how a marker of conclusion such as alltså can be used with meanings such as that is or in other words. The developments undergone by alltså can be summarised as:

a) Adverb with consecutive meaning $\rightarrow$ marker of conclusion $\rightarrow$ request for confirmation

b) Adverb with consecutive meaning $\rightarrow$ marker of conclusion $\rightarrow$ marker of reformulation (summarising rephrasing, resuming a topic) $\rightarrow$ elaborative or paraphrastic reformulation marker (clarifying, explaining, expanding, refining)

It is difficult to capture all the functions of alltså on the basis of written data and translations. The discourse marker has a number of local or global functions at the discourse level which makes it difficult to say how many functions we should distinguish. Vaskó and Fretheim (1997: 234) comment that 'it is extremely hard to get at the "superstructural" rules constraining the [Norwegian] particle altså at the discourse level, which makes it all the more difficult to delimit the function(s).' Moreover, there are differences between the languages. We noted, for example, that German also with a context-adjusting function could be a frame with connecting function. In Swedish, on the other hand, alltså as a frame in pre-front position has mainly attention-getting function. Another difference between German and Swedish alltså is that while German also can be a translation of well one would have to use a different translation in Swedish.

This study has made it possible to compare the Swedish alltså, German also and English so and thus to widen the perspective to some typological observations. In Table 4, I compare the main meanings of Swedish alltså, English so and German also.

I did not find any examples of the non-paraphrastic use of also in the EnglishGerman corpus but examples might have turned up in a larger corpus. The distinctions have been validated by translations. However, certain discourse functions may have a zero correspondence. For example, the function of emphasis and intensification associated with alltså in final function was often not translated. 
Table 4. A comparison between Swedish alltså, German also and English so.

\begin{tabular}{|c|c|c|c|}
\hline & $\begin{array}{l}\text { Swedish } \\
\text { alltså }\end{array}$ & $\begin{array}{l}\text { German } \\
\text { also }\end{array}$ & $\begin{array}{l}\text { English } \\
\text { so }\end{array}$ \\
\hline Adverb expressing conclusion (non-DM use) & $\mathrm{x}$ & $\mathrm{x}$ & $\mathrm{x}$ \\
\hline Marker of conclusion & $\mathrm{x}$ & $\mathrm{x}$ & $\mathrm{x}$ \\
\hline Request for confirmation & $\mathrm{x}$ & $\mathrm{x}$ & \\
\hline $\begin{array}{l}\text { Reformulating } \\
\text { (non-paraphrastic) }\end{array}$ & & & \\
\hline $\begin{array}{l}\text { recapitulating, resuming a thread, summarising) } \\
\text { Reformulating (paraphrastic) }\end{array}$ & $\mathrm{x}$ & $(\mathrm{x})$ & - \\
\hline elaborating, expanding, refining) & $\mathrm{x}$ & & \\
\hline & $\mathrm{x}$ & - & \\
\hline In imperatives ${ }^{4}$ & - & $\mathrm{x}$ & $\mathrm{x}$ \\
\hline Framing marker $(=$ well $)$ & - & $\mathrm{x}$ & - \\
\hline $\begin{array}{l}\text { Framing marker } \\
(=\text { now look })\end{array}$ & $\mathrm{x}$ & $\mathrm{x}$ & $\mathrm{x}$ \\
\hline $\begin{array}{l}\text { Marker of hesitation } \\
(=\text { well })^{5}\end{array}$ & - & $\mathrm{X}$ & $\mathrm{X}$ \\
\hline emphasis or intensification & + & - & - \\
\hline (other) non-DM uses & - & - & $\begin{array}{c}\text { degree adverb, } \\
\text { manner adverb, } \\
\text { so that }\end{array}$ \\
\hline
\end{tabular}

\section{References}

Aijmer, Karin (1997). "I think - an English modal particle". In: Swan, Toril; Westvik, Olaf Jansen (eds.). Modality in the Germanic languages. Proceedings of the IXth International Symposium on Languages. Berlin: Mouton de Gruyter, pp. 1-48. Aijmer, Karin; Altenberg, Bengt; Johansson, Mats (1996). "Text-based contrastive studies in English. Presentation of a project". In: Aijmer, Karin; Altenberg, Bengt; Johansson, Mats (eds.). Languages in Contrast. Papers from a Symposium on Textbased Cross-Linguistic Studies in Lund, 4-5 March 1994. Lund: Lund University Press, pp.73-85.

Aijmer, Karin; Altenberg, Bengt (2002). "Zero translations and cross-linguistic equivalence: Evidence from the English-Swedish Parallel Corpus". In: Breivik, Leiv Egil; Hasselgren, Angela (eds.). From the Colt's mouth... and others'. Language Corpora Studies in Honour of Anna-Brita Stenström. Amsterdam/New York, pp. 19-41.

Aijmer, Karin; Simon-Vandenbergen, Anne-Marie (2003). "Well in English, Swedish and Dutch". Linguistics 41-6: 1123-1161.

4. No example found in the Swedish data but it does not seem to be impossible to use alltsa before imperatives.

5. I did not find any examples of hesitation in my Swedish data. However Lehti-Eklund (2003:152) found examples where alltså could be translated with well and marked hesitation. 
Aijmer, Karin; Simon-Vandenbergen, Anne-Marie (eds.) (2006). Pragmatic Markers in Contrast. Amsterdam: Elsevier.

Aijmer, Karin; Simon-Vandenbergen, Anne-Marie (forthcoming). The Semantic Field of Modal Certainty. A Study of English Adverbs.

Altenberg, Bengt; Aijmer, Karin (2000). "The English-Swedish Parallel Corpus: A resource for contrastive research and translation studies". In: Mair, Christian; Marianne Hundt (eds.). Corpus Linguistics and Linguistic Theory. Papers from the 20th International Conference on English Language Research on Computerized Corpora (ICAME 20) Freiburg im Breisgau 1999. Amsterdam/Philadelphia: Rodopi, pp. 15-33.

Auer, Peter (1996). "The pre-front field in spoken German and its relevance as a grammaticalization position". Pragmatics 6(3): 295-322.

Baker, Mona (1995). "Corpora in Translation Studies: An overview and some suggestions for future research. Target 7(2): 223-243.

Behrens, Bergljot (2004). "Cohesive ties in translation: A contrastive study of the Norwegian connective dermed". Languages in Contrast 5(1): 3-31.

Blakemore, Diane (2002). Relevance and Linguistic Meaning. The Semantics and Pragmatics of Discourse Markers. Cambridge: Cambridge University Press.

Brinton, Laurel J. (1996). Pragmatic Markers in English. Grammaticalization and Discourse Functions. Berlin/New York: Mouton de Gruyter.

Brinton, Laurel J. (1998). "The flowers are lovely; only, they have no scent": The evolution of a pragmatic marker". In: Borgmeier, Raimund; Grabes, Herbert; Jucker, Andreas J. (eds.). Anglistentag 1997 Proceedings, pp. 9-33.

Brinton, Laurel J. (2001). "From matrix clause to pragmatic marker. The history of look-forms". Journal of Historical Pragmatics 2(2): 177-199.

Cuenca, Maria Josep (forthcoming). "Pragmatic markers in contrast: the case of well". Journal of Pragmatics.

Dyvik, Helge (1998). "A translational basis for semantics". In: Johansson, Stig; Oksefjell, Signe (eds.). Corpora and Cross-Linguistic Research: Theory, Method, and Case Studies. Amsterdam: Rodopi, pp. 51-86.

Dyvik, Helge (2004). "Translations as semantic mirrors: from parallel corpus to wordnet”. In: Aijmer, Karin; Bengt Altenberg (eds.) Advances in Corpus Linguistics. Papers from the $23^{\text {rd }}$ International Conference on English Language Research on Computerized Corpora (ICAME 23). Amsterdam: Rodopi, pp. 311-326.

Eriksson, Mats (1998). “Ju, väl, då, va, alltså”. In: Eriksson, Mats; Schenström, Amelie (eds.) Studier $i$ Stockholmsspråk 1. Stockholms Universitet: Institutionen för nordiska språk, pp. 75-120.

Erman, Britt; Kotsinas, Ulla-Britt (1993). "Pragmaticalization: the case of ba' and you know”. Acta Universitatis Stockholmiensis, New Series 10, pp. 76-93.

Fernandez, M.M. Jocelyne (1994). Les particules énonciatives dans la construction du discours. Paris: Presses Universitaires de France.

Ferrara, Kathleen W. (1997). "Form and function of the discourse marker anyway: implications for discourse analysis". Linguistics 35, 343-378.

Fleischman, Suzanne; Yaguello, Marina (2004). "Discourse markers across languages". In: Moder, Carol Lynn; Aida Martinovic-Zic (eds.) Discourse across Languages and Cultures. Amsterdam/Philadelphia: John Benjamins, pp. 129-147.

Fraser, Bruce (1996). "Pragmatic markers". Pragmatics 6(2): 167-190. 
Fretheim, Thorstein (2000). "Procedural encoding of propositional attitude in Norwegian conditional clauses". In: Andersen, Gisle; Fretheim, Thorstein (eds.) Pragmatic Markers and Propositional Attitude. Amsterdam/Philadelphia: John Benjamins, pp. 53-84.

Fretheim, Thorstein; Johansson, Stig (2002). "The semantics and pragmatics of the Norwegian concessive marker likevel: Evidence from the English-Norwegian Parallel Corpus". In: Breivik, Leiv Egil; Hasselgren, Angela (eds.). From the Colt's mouth... and others'. Language Corpora Studies in Honour of Anna-Brita Stenström. Amsterdam/New York, pp. 81-101.

Giacalone Ramat, Anna (1998). "Testing the boundaries of grammaticalization". In: Giacalone Ramat, Anna; Hopper, Paul J. (eds.) The Limits of Grammaticalization. Amsterdam/Philadelphia: John Benjamins, 107-127.

Gülich, Elisabeth; Kotschi, Thomas (1996). "Textherstellungsverfahren in mündlicher Kommunikation. Ein Beitrag am Beispiel des Französichen”. In: Motsch, Wolfgang (ed.). Ebenen der Textstruktur. Sprachliche und kommunikative Prinzipien. Tübingen: Max Niemeyer, pp. 37-80.

Halliday, M. A. K.; Hasan, Ruquaiya (1976). Cohesion in English. London: Longman. Hansen, Maj-Britt Mosegaard (1998). The Function of Discourse Particles. A Study with Special Reference to Spoken Standard French. Amsterdam/Philadelphia: John Benjamins.

Hansen, Maj-Britt Mosegaard (2006). "A dynamic polysemy approach to the lexical semantics of discourse markers (with an exemplary analysis of French toujours)". In: Fischer, Kerstin (ed.) Approaches to Discourse Particles. Amsterdam: Elsevier, pp. 21-41.

Hopper, Paul (1991). "On some principles of grammaticization". In: Traugott, Elizabeth C.; Heine, Bernd (eds.). Approaches to Grammaticalization. Amsterdam: John Benjamins. Vol.1: pp. 17-35.

Johansson, Stig (1997). "Using the English-Norwegian Parallel Corpus- A corpus for contrastive analysis and translation studies". In: Lewandowska-Tomasczyk, Barbara; Melia, J. (eds.). PALC '97. Practical Applications in Language Corpora. University of Lodz, pp. 282-286.

Lehmann, Christian (1985). "Grammaticalization: Synchronic variation and diachronic change". Lingua e Stile 20: 303-316.

Lehti-Eklund, Hanna (1990). Från adverb till markör i text. Studier i semantisk-syntaktisk utveckling i äldre svenska. Skrifter utgivna av svenska litteratursällskapet i Finland 561. Helsingfors.

Lehti-Eklund, Hanna (1997). “Alltså som diskurspartikel”. In: Haapamäki, Saara (ed.). Svenskan i Finland 4. Åbo, pp. 75-83.

Lehti-Eklund, Hanna (2003). "The grammaticalization of alltså and således: Two Swedish conjuncts revisited". In: Cuyckens, Hubert; Dirven, René; Taylor, John R. (eds.) Cognitive Approaches to Lexical Semantics. Berlin: Mouton de Gruyter, pp. 123-162.

Nilsson, Jenny (2005). Adverb i interaktion. Göteborgsstudier i nordisk språkvetenskap 4. Göteborg.

Noël, Dirk (2003). "Translations as evidence for semantics. An illustration". Linguistics 41(4): 757-785.

Nølke, Henning (1999). "Utilise donc altså! -Altså brug dog donc! Études comparatives de connecteurs et le réseau contrastif français-danois". In: Skytte, Gunver; 
Sabatini, Francesco (eds.) Linguistica testuale comparativa, Études romanes 42. Copenhagen: Museum Tusculanum, pp. 37-55.

Rossari, Corinne (1994). Les opérations de reformulation. Analyse du processus et des marques dans une perspective contrastive français- italien. Berne: Lang.

Schiffrin, Deborah (1987). Discourse markers. Cambridge: Cambridge University Press. Simon-Vandenbergen, Anne-Marie; Aijmer, Karin (2003/2004). "The expectation marker of course". Languages in Contrast 4(1): 13-43.

Tabor, Whitney; Elizabeth C. Traugott (1998). "Structural scope expansion and grammaticalization". In: Giacalone Ramat, Anna; Hopper, Paul J. (eds.) The Limits of Grammaticalization. Amsterdam/Philadelphia: John Benjamins, pp. 229-272.

Traugott, Elizabeth C (1997 [1995]). "The role of the development of discourse markers in a theory of grammaticalization". Paper presented at ICHL XII, Manchester 1995. Accessed on the internet http://www.stanford.edu/ traugott/papers/discourse.pdf

Traugott, Elizabeth; Dasher, Richard B. (2002). Regularity in Semantic Change. Cambridge: Cambridge University Press.

Vaskó, Ildiko; Fretheim, Thorstein (1997). "Some central pragmatic functions of the Norwegian particles altså and nemlig". In: Swan, Toril; Westvik, Olaf Jansen (eds.). Modality in the Germanic Languages. Proceedings of the IXth International Symposium on Languages. Berlin: Mouton de Gruyter, pp. 233-292. 